This item was submitted to Loughborough's Research Repository by the author.

Items in Figshare are protected by copyright, with all rights reserved, unless otherwise indicated.

\title{
Italian municipalities and the politics of financial derivatives: rethinking the Foucauldian perspective
}

PLEASE CITE THE PUBLISHED VERSION

http://dx.doi.org/10.1177/1024529415581969

\section{PUBLISHER}

Sage (@ The Authors)

\section{VERSION}

AM (Accepted Manuscript)

\section{PUBLISHER STATEMENT}

This work is made available according to the conditions of the Creative Commons Attribution-NonCommercialNoDerivatives 4.0 International (CC BY-NC-ND 4.0) licence. Full details of this licence are available at: https://creativecommons.org/licenses/by-nc-nd/4.0/

\section{LICENCE}

CC BY-NC-ND 4.0

\section{REPOSITORY RECORD}

Lagna, Andrea. 2019. "Italian Municipalities and the Politics of Financial Derivatives: Rethinking the Foucauldian Perspective". figshare. https://hdl.handle.net/2134/22512. 


\title{
Italian Municipalities and the Politics of Financial \\ Derivatives: Rethinking the Foucauldian Perspective
}

\author{
Andrea Lagna
}

\begin{abstract}
This study examines the use of interest rate swaps by Italian municipalities during the 2000-2014 period. Through a constructive critique of Foucauldian political economy, it argues that local administrators did not enter the swaps market to perform and depoliticize the disciplinary power of financialized discourses. The evidence suggests many more layers of historical complexity underlie the municipalities' actions than a Foucauldian approach can grasp. Local governments used swaps to circumvent the budget constraints imposed by the European Stability and Growth Pact. In this sense, municipalities acted more for political-strategic than for performative and depoliticized purposes. Rethinking the dimensions of performativity and disciplinary power - through an approach that is more sensitive than Foucauldian analysis to historical agency and asymmetrical power relations - is crucial to address the differential and politically shaped contours of financialization across the globe.
\end{abstract}

Keywords: derivatives; municipalities; Italy; austerity; varieties of financialization; politics of financialization; Foucauldian political economy. 


\section{Introduction}

The existing literature on financialization is an invaluable resource for exploring how modern finance pervades human relations with its market-based practices and technologies. ${ }^{1}$ In this regard, this literature could provide appropriate analytical tools for critically examining the striking growth of derivatives markets and their use in specific contexts, such as Italy. ${ }^{2}$ However, despite its insightful analyses and progressive ideas, this body of research has a weakness: it does not devote sufficient attention to examining how financialization spreads unevenly across the world depending on distinct power relations and processes of institution building. In brief, the debate fails to capture what several scholars describe as the varieties of financialization and the politics producing such heterogeneity (Engelen, et al., 2010; Engelen \& Konings, 2010: 608-9; Montgomerie, 2008: 241; Nölke, et al., 2013).

The difficulty of accounting for the differential and politically shaped trajectories of financialization is particularly evident in the work of Foucault-inspired political economists. Authors such as Aitken (2007), De Goede (2005) and Langley (2009) conceptualize present-day financial expansion as a system of beliefs that individuals perform - that is, create and reproduce - in their daily habits. Such a conceptualization implies that the more individuals repeat financial practices, the more such routines consolidate into a depoliticized - meaning removed from political influence - mode of governance, the power of which disciplines society as a whole. Clearly, Foucauldians acknowledge the role of human agency in constructing financialized phenomena. In this regard, they could provide the tools to describe the actors who shape financialization in its context-specific features and explain how and why they do so. Yet, by extensively relying on the two intertwined notions of 
performativity and disciplinary power, the Foucauldian framework renders financialization a politically inactive entity that replicates similar institutions everywhere. Indeed, when everyone is regarded as performing and depoliticizing omnipresent financialized discourses, it is difficult to appreciate how individuals relate to such discursive structures through different perceptions, objectives and capabilities - ultimately rendering financialization a globally heterogeneous and highly politicized formation.

This article constructively engages with Foucauldian studies on finance. It does so through an agency-centred perspective that returns the dimension of power to the level of historical actors, their conflicts and the institutions mediating agential interaction (Knafo, 2010; Konings, 2010). In so doing, the study advances a conceptual framework that is more sensitive than the Foucauldian one to the actual politics that shape financialization in distinct institutional environments. Drawing on this approach, the article investigates the case of Italian municipalities and their controversial use of interest rate swaps during the 2000-2014 period. It argues that local administrators began employing swaps to circumvent the budget constraints imposed by the European Stability and Growth Pact. In other words, far from performing and depoliticizing the use of derivatives - the logical conclusion that Foucauldian scholars would draw - Italian municipalities entered the swaps market en masse as a political-strategic move against an unsustainable regime of fiscal austerity. In so doing, local authorities contributed to the unfolding of derivatives-based practices as a variegated and politically meaningful phenomenon.

The argument in the article is developed in four steps. First, it rethinks the Foucauldian conceptual apparatus from the perspective of the agency-centred method. Second, the work explores the specificities of the Italian case, focusing on the 
historical dynamics - the key agents, power struggles and processes of institutional construction - that led to the emergence of derivatives in local finance from the late 1990s onwards. Third, the study explains the derivatives-based tactics that municipalities employed during the 2000-2008 period. This section shows, in practical terms, the political-strategic - rather than performative and depoliticized character of local authorities' accounting devices. Finally, the last section concludes by reviewing the post-2008 regulatory developments in Italy and the derivatives excesses of other local authorities worldwide.

\section{Rethinking performativity and disciplinary power in the age of financialization}

Foucauldian political economists explore financialization as a web of interrelated discourses that individuals perform in their daily routines. In so doing, modern financial practices permeate social relations with their disciplinary power, and they tend to become a depoliticized sphere of human activity. However, although this financial discipline is pervasive, individuals do not completely internalize it. This partial internalization leaves space for the existence of dissent and the re-politicization of financial affairs (Aitken, 2007; De Goede, 2005; Langley, 2009).

To cite an example of how this framework can be operationalized, municipalities support the discourse according to which using interest rate swaps is a rational way to hedge the risk of interest-rate volatility. Thus, as they use these speculative instruments to manage fluctuations in the underlying financial variables, they also allow the complexities of derivative markets - such as various swap curves, the London Interbank Offered Rate (LIBOR), the International Swaps and Derivatives Association (ISDA) Master Agreement and so forth - to gradually pervade everyday 
life. In this sense, they perform the discourse of derivatives-based risk management and enable its reproduction and diffusion deep within the social fabric. At this point, the disciplinary power of such discourse has become so pervasive that the use of derivatives turns into a depoliticized and technical matter that is largely removed from democratic influence. Clearly, regulators might intervene to shape derivatives markets differently, as indicated by the current reforms of over-the-counter (OTC) derivatives markets (FSB, 2010). ${ }^{3}$ However, policy makers, market participants and the general public do not ultimately entertain any doubt about the use of derivatives as a valid means of managing financial risks compared with other - and possibly less speculative - forms of risk governance.

At first glance, a Foucauldian approach appears to provide a convincing conceptualization of agency that could help account for who constructs the differential and politically shaped trajectories of financialization and how and why they engage in such processes. However, the two concepts of performativity and disciplinary power produce an inactive perspective of agency that prevents scholars from appreciating financialization as a political and heterogeneous construction.

As Konings (2009b: 73-9) explains, viewing actors as performing finance through discursive iterations confers excessive coherence to the norms that individuals experience in numerous specific ways. For instance, ordinary people may have different concerns and strategic capabilities compared with, for example, Henry Paulson or Richard Fuld - two prominent figures in the United States subprime crisis. ${ }^{4}$ However, performativity tends to obscure these differences by implying that all agents are equal performers of financialization. Whether an individual is an influential chief executive officer of a financial corporation or a humble university professor does not matter. Diversity is generally irrelevant because all actors 
ultimately perform and depoliticize the disciplinary power of financialization that permeates society as a whole. Thus, although historical agents are acknowledged, they are nevertheless emptied of their resources - because the power dimension lies beyond the reach of individual forces and instead resides in the ethereal space of financialization as a performative-discursive regime (De Goede, 2005: 8-13; 2006: 911; Langley, 2007: 27-31).

Therefore, in an exploration of the differential and politically significant features of financialized dynamics, two aspects of social construction are concealed. First, certain actors clearly advance the discourses of financialization to strengthen their actions against others. By emphasizing the diffuse character of disciplinary power while neglecting asymmetrical relations amongst agents, Foucauldian political economists fail to capture the actual actors who adapt financialization differently and to explain how they do so through political struggles unfolding in specific circumstances. Second, agents do not simply perform and depoliticize the dominant discourses of financialization; rather, they construct - or relate to - them in a strategic sense. Agents do so to gain margins of control over the surrounding reality that they experience (Konings, 2009b: 75), a context that is always permeated by political conflicts and that is never truly depoliticized, even when it acquires a "logic of calculability and an appearance of scientific objectivity that places its fundamental assumptions [...] beyond discussion and debate” (De Goede, 2005: 3).

To clarify, the central problem of Foucauldian political economy is that its conceptual apparatus is geared towards exploring how discourses constitute agential subjectivities - and in turn the entire society - through habitual behaviours. Undoubtedly, Foucauldians are able to capture this aspect accurately. However, while doing so, they fail to account for how discursive structures also enable the 
development of agential tactics. Actors are depicted as generally idle and driven by discourses the construction of which they hardly influence. In other words, "what remains insufficiently developed is a conception of structuration as enabling, i.e. a conception of symbolic and institutional formations, not only as constituting actors, but also as facilitating their ability to act in the world” (Konings, 2010: 63 emphasis in original). Beyond the routine-based character of human agency and its habitual role in social construction, it is also crucial to explore the capacity of agents to imagine future alternative worlds and to contextualize their forward-thinking actions within the pragmatic contingencies of the present (Emirbayer \& Mische, 1998).

This critique highlights the necessity of developing a more historically sensitive method than the Foucauldian approach to interpret the politics of financialization and its multi-faceted contours across space. In this regard, this study builds on the central notion that power should not be conceptualized as an ubiquitous apparatus of disciplinary control (Foucault, 1977: 176-7). It is instead fundamental to place power at the level of historical agency, once institutions or discourses are viewed as the mediating ground of agential relations (Knafo, 2010: 504). In other words, the relationship between agency and institutions should be understood to articulate in a 'triadic' manner in that it entails not an agent-structure dualism, but an agent-agent interaction that is mediated by complex institutional architectures (Konings, 2010: 68). The subtle difference is that this triadic perspective on human interaction describes a scenario in which agents do not face objectified power structures, but rather interact with other agents by continuously manipulating - or, more simply, relating to - mediating institutions.

A triadic context has profound implications for the way in which we 
conceptualize power. Here, power becomes the agential ability to manipulate institutions to gain leverage in a particular scenario. It is interpreted at the level of praxis where certain agents are willing and intellectually able to experiment with existing institutions, to risk failure and become lost in creative confusion and, finally, to advance innovative ideas that could become widely acknowledged norms. Other agents, on the contrary, gradually abandon their attempt to empower themselves, deactivating their creativity and agreeing to experience reality according to extant rules. In this sense, new institutions provide leverage to those who advanced them through experimenting and reshaping while simultaneously eliminating opportunities for others (Konings, 2010: 70). However, far from becoming a structural reification of human relations, the newly created institutional environment always presents opportunities for further manipulation (Lagna, 2015: 211-2). This triadic conceptualization of institutional construction reveals a paradox that becomes prolific for empowering purposes. When agents create new institutions, these institutions do not simply constrain other actors, but enable them to experience imperatives in multiple ways (Knafo, 2010; Konings, 2010). As the following sections demonstrate, this aspect is fundamental to comprehend how Italian neoliberal forces exerted power by constructing market-oriented institutions. Yet, municipalities accepted such constraints on their own strategic terms, eventually transforming the restrictive rules to which they were initially subjected.

In brief, the agency-centred approach does not regard social construction as a process in which individuals perform and depoliticize present-day financial expansion. Rather, it places power at the level of agency and offers actors the ability to interpret and transform institutions on the ground. This historically sensitive framework thus allows us to properly recognize financialization as a highly 
politicized and variegated process of institutional formation in the making.

The next section begins to explore the specificities of the Italian case. It examines the historical circumstances - the key actors, power struggles and processes of institution building - that prompted the introduction of derivatives in Italian local finance.

\section{Dismantling finanza derivata and introducing financial}

\section{derivatives}

Italian local authorities began to approach OTC derivatives markets in the mid1990s. ${ }^{5}$ Two interconnected processes were decisive in this regard. First, Italy complied with the Stability and Growth Pact in line with the objective of joining the Economic and Monetary Union (EMU) in 1999. Second, the country underwent a process of fiscal and administrative decentralization from the central state to local governments. Both aspects are examined in turn.

During the 1990s, Italy faced the imperative of reducing public deficits and debt owing to its commitment to satisfy the Maastricht convergence criteria prior to EMU admission in 1999. A domestic alliance comprising neoliberal-minded technocrats and centre-left politicians (henceforth, neoliberal reformists) came to power and strongly supported the country's participation in this project. ${ }^{6}$ For them, European integration represented an important opportunity because it functioned as an 'external constraint' (Dyson \& Featherstone, 1996; Sbragia, 2001) on the traditional political and business establishment, which heavily depended on the dissipation of public finance (Pasquino, 2000: 79), control over state-owned enterprises (Bianchi, 
1987) and, finally, a corporate governance regime that worked to the advantage of majority shareholders (Deeg, 2005). This key objective of neoliberal reformists to keep the old establishment at bay explains Italy's eagerness to join the EMU against all odds. In practice, however, other more feasible options were available (Quaglia, 2004: 1101-3).

Thus, as neoliberal actors enhanced their power position by modernizing Italy in line with the market-oriented dynamics of the EMU, they strove to ensure that the country complied with the Stability and Growth Pact in 1997. The latter made European states adhere to low budget deficits through a system of sanctions (Heipertz \& Verdun, 2004; 2005), and inevitably, this austere architecture exerted pressures on European economies - both their central and local administrations - to reform their financing strategies. Indeed, the Italian budget law for the year 1999 included a comprehensive plan for the coordination of public finance known as Patto di Stabilità Interno (Internal Stability Pact), which is the domestic equivalent of the Stability and Growth Pact (Italian Parliament, 1999a). This plan established a maximum limit on the annual expenditures of regions, provinces and municipalities.

In addition to advocating Italy's strict compliance with the Stability and Growth Pact, neoliberal reformists embraced the benefits of fiscal and administrative devolution, a bipartisan theme that was also favoured by centre-right forces such as the Northern League (Alonso, 2012: 197-8). The project gained momentum in the first of four consecutive laws in 1997 (Italian Parliament, 1997a; 1997b; 1998; 1999b), and it was eventually finalized with the consolidated law on local authorities in 2000 and the reform of the constitutional law in 2001 (Italian Government, 2000; Italian Parliament, 2001a). This last legislative step granted local authorities broader margins of autonomy in managing revenues, expenditures and debt. In other words, 
these reforms began to dismantle the old system of local finance that policy makers had until then defined as finanza derivata (Italian Parliament, 2010b: 5). ${ }^{7}$ This term implied that the revenues of local authorities ‘derived from’ state transfers with the exception of the limited income that came from locally levied taxes. In simple terms, the state collected most of the inland revenues and then transferred funds to local administrations. When state transfers were insufficient, local authorities financed investments through fixed-rate loans from two public institutes, namely, Cassa Depositi e Prestiti and Consorzio di Credito per le Opere Pubbliche (Rosati, 2009: 4).

Collectively, Italy's adherence to the Stability and Growth Pact and the dismantling of finanza derivata created a radically different scenario for municipalities. Indeed, while the level of state transfers began to decline in response to budgetary constraints, local administrations obtained greater autonomy in policies concerning revenues, expenditures and debt. In this context, they were allowed to approach financial markets, instruments and actors beyond the traditional statecontrolled sphere (Saccomanni, 2007: 17). They were thus able to familiarize themselves with the use of bonds and derivatives-based techniques, which appeared to be attractive solutions compared with other relatively expensive forms of financing, such as loans from Cassa Depositi e Prestiti. In essence, local authorities began to shift away from the regime of state-led finanza derivata towards a market-based one involving financial derivatives, amongst other tools.

Regulation concerning the use of derivatives by local authorities mirrored the political-economic trends described above. The first blow to the old system of subsovereign finance occurred in 1994 when Italy ended the monopoly of Cassa Depositi e Prestiti and Consorzio di Credito per le Opere Pubbliche in the allocation of loans to local governments. Municipalities were now allowed to enter into debt by issuing 
bonds. Consequently, they were obliged to use currency swaps in the case of fixedincome positions that were denominated in foreign currencies (Italian Parliament, 1994; MEF, 1996). No other regulation on the use of other types of derivatives, such as interest rate swaps, was implemented. Thereafter, the government began to establish more specific directives concerning all kind of derivatives instruments available to local authorities during the 2001-2004 period (Italian Parliament, 2001b; 2003; MEF, 2003; 2004). These directives were successively updated several times after 2004 (Italian Parliament, 2006; MEF, 2007a; 2007b), but their content remained substantially unchanged until 2008, when the government imposed a moratorium that prevented local authorities from entering into new derivatives contracts. ${ }^{8}$

The key point regarding this regulatory framework is that, as the next section shows, it was inadequate and it enabled many municipalities to use derivatives in unorthodox ways. Furthermore, it was designed and implemented during the centreright administration led by Silvio Berlusconi, which came into power in 2001. As Berlusconi’s political-economic platform was rather hesitant towards respecting European dictates (Ginsborg, 2001: 297), the regulation concerning the use of derivatives by local authorities was clearly part and parcel of a broader policy regime that vaunted the use of financial chicanery as a method to circumvent the constraints of the Stability and Growth Pact. ${ }^{9}$

\section{Municipalities and the strategic adoption of interest rate}

\section{swaps}

Thus far, this study has explored the agents, power relations and dynamics of institution building that led to the emergence of financial derivatives as debtmanagement tools in Italian local finance. It has shown that neoliberal reformists 
came to power in Italy during the 1990s and challenged the traditional political-cumbusiness establishment by introducing fiscal austerity and market-oriented reforms in line with the EMU and the Stability and Growth Pact. In addition to this, neoliberal reformists supported the devolution of fiscal and administrative authority. On the one hand, Italy's compliance with the Stability and Growth Pact caused a reduction of fund transfers from the central state to the sub-sovereign level. On the other hand, the process of decentralization granted local authorities greater autonomy in the administration of their finances and the possibility to use bonds and derivatives. These two trends shaped an institutional environment in which local governments embraced the practices and instruments of market-based finance. From 2001 onwards, the Berlusconi administration - praising the adoption of accounting deception against European directives (Flores D’Arcais, 2011; Ginsborg, 2003) - implemented flawed regulation to oversee the use of derivatives by local authorities.

The following subsections depart from the general political-economic context and examine the distinct derivatives techniques that Italian municipalities adopted. First, a standard example of a municipal financing plan that involved interest rate swaps is presented. Second, a key accounting artifice highlighting how numerous municipalities embraced financial innovation for political-strategic purposes is discussed. In so doing, the following subsections demonstrate that the neoliberal reforms did not simply constrain municipalities but enabled them to engage in manipulation on their own terms.

\section{Interest rate swaps: an example}

Interest rate swaps are typically used to optimize the costs of municipal liabilities by restructuring the debt position. Such debt restructuring aims to save part of financial 
resources that were previously used to service debt, therefore generating greater liquidity in a municipal budget.

For instance, in the simple case of a municipality in the Apulia region, debt restructuring operations consisted in closing over sixty fixed-rate loans - totalling approximately €10 million - which were borrowed from the state-controlled bank Cassa Depositi e Prestiti during the period between 1997 and $2004 .{ }^{10}$ Over the same period, the municipality issued fixed-rate bonds (3.75 per cent) for the same value and with a 20-year maturity. A specialized private bank assisted in all phases of the issuance of these municipal bonds and underwrote the entire lot by holding it on its balance sheet. In other words, the municipality had the opportunity to eliminate its debt (loans) with Cassa Depositi e Prestiti and instead to issue bonds to exploit favourable market rates.

Interest rate swaps were initially employed in 2006. Controversially, the same private bank involved in the municipal bonds proposed that the municipality enter into a fixed-to-floating swap. Recall that the swap does not substitute for the municipality's previous commitments on the 20-year-maturity bond. The swap is a distinct contract that operates akin to a bet. In the fixed-to-floating case of the Southern Italian municipality, the bank was the fixed-rate payer, whereas the municipality was the floating-rate payer. In this type of swap, the nature of the bet is that the fixed-rate payer has a negative flow of funds towards the floating-rate payer when the interest rate declines and vice versa. In our case, owing to the interest-rate scenarios, the municipality initially had a positive flow of funds. In practical terms, the municipality still paid a fixed rate of 3.75 per cent on its bonds, but these interest payments were discounted by a certain number of basis points in line with the flow of funds that derived from the swap bet in variable terms. However, a problem emerged 
once interest rates rose after the 2008 collapse of Lehman Brothers, turning the municipality’s initially positive flows negative. Thus, the opportunity was not as attractive as it had first appeared.

In general terms, many other municipalities across the country experienced similarly negative circumstances, regardless of the specific variables and features of their derivatives contracts. According to data from the Bank of Italy (2009: 22; 2014: 22), 310 municipalities had a negative exposure to derivatives, representing a market value of $€ 343$ million in December 2005. This figure increased to 619 municipalities with a negative market value of $€ 686$ million by December 2007. In December 2009 that is, after the 2008 moratorium - the number of municipalities declined to 429 with a negative market value of $€ 569$ million. Finally, the latest data available from June 2014 indicate that 114 municipalities have a negative exposure to derivatives, with a negative market value of $€ 390$ million. However, note that these quantitative data only account for municipalities. If we also include provinces and regions, the negative market value increases (in absolute terms) to over $€ 1$ billion in June 2014. Furthermore, these data only concern the activities of financial intermediaries that operate in Italy. However, larger local authorities typically contracted with foreign operators, which account for an approximately 60 per cent market share. In other words, the data represent an approximation that underestimates a much broader phenomenon (Franco, 2009: 26-7). According to the Financial Times, losses could reach $€ 10$ billion if not only swaps but also sinking funds are included (Sanderson, et al., 2010).

\section{A key accounting device: the upfront}

The events described above demonstrate how local administrators adopted interest 
rate swaps to compensate for the budgetary restrictions resulting from the marketoriented reforms of local finance. By more actively managing municipal debt, the local authority cited above attempted to exploit lower interest rates relative to the rate for its fixed-rate bonds. Such practices can appear as instances of depoliticized performativity in which municipalities subscribed to the disciplinary power of financialization. In other words, local authorities may have embraced the discourse of active debt management (Cassard \& Folkerts-Landau, 1997) and entered derivatives markets as the latest financial innovation. However, local authorities do not appear to have embraced such a discourse, or at least, such motivations do not seem to be an important element of the story. Rather, the scenario is replete with politically significant implications on the part of municipalities and their resistance towards the austere system imposed by the Stability and Growth Pact. This aspect becomes clear once we thoroughly examine the strategic modalities through which most local governments employed swaps. To do so, we focus on the accounting elements of the phenomenon, particularly the so-called upfront.

Under growing budget constraints, many municipalities attempted to make a virtue of the available practices by manipulating them. In this regard, the upfront was the key aspect that induced local authorities to become overexposed to swaps. Generally, the upfront is a sum that banks advanced to municipalities to place the contract in a market-neutral position, which occurred when the swap was of a non-par type. When the two parties entered into the contract, the swap hence presented a negative market value for one of the two parties (in this case, a given municipality). Thus, the bank brought the contract to par by advancing an upfront sum to the municipality that should be equivalent to the negative market value to which the local government was exposed at the signing of the contract (Rosati, 2009: 1-2). At this 
point, "in the revolving-door world of Italian local politics, each new administration wanted its own upfront, so asked their bankers to restructure the deal to release more cash in advance” (Sanderson, et al., 2010). Obviously, banks welcomed such an opportunity for easy profit from sub-sovereign markets by using a declaration form in which the head of financial services in a given municipality agreed to be considered a 'qualified operator' (operatore qualificato) - that is, an expert who is able to understand the mathematics of complex financial risks. ${ }^{11}$ In so doing, "the terms of the swap tended to become restrictive each time. Some banks covered the cost of the upfront fee by pricing the interest rate swap more aggressively, so that only in unusual circumstances would the entity receive more each period than it paid out” (Sanderson, et al., 2010).

The 'upfront' was crucial because it affected municipal budget policies through an accounting artifice. Municipalities regarded the upfront as revenue rather than debt, circumventing the budget constraint of 15 per cent in the debt-to-revenue ratio as imposed by the pact of internal stability. In other words, municipalities artificially increased the revenue side of the ratio while leaving their debt position essentially unchanged. Paradoxically, the upfront became a virtue for the purposes of achieving political consensus at the local level (Carlini, 2010). Indeed, this financial expedient became important in a context in which the devolution of fiscal administration and the decentralization of political party structures were enhancing the power position of sub-national elites and their patron-client relations (Galli Della Loggia, 2013; Hopkin, 2008).

\section{Current scenarios and the experience of other countries}

By deploying the strategies described above, Italian local authorities transformed their 
use of derivatives into a heated controversy. In the summer of 2008, the majority of swaps positions presented substantial losses for municipalities. This situation forced the government to enact the above-mentioned moratorium that prevented local administrations from entering into derivatives contracts until a new regulation was agreed upon (Italian Government, 2008; Italian Parliament, 2008a; 2008b). For five years, policy makers developed on a framework to regulate the use of derivatives in local finance and examined aspects such as the types of instruments that should have been available to local authorities, the derivatives components that municipalities could have included in their financing strategies and, finally, the transparency of information that should be explained in both the contracts and the annual municipal budget reports (MEF, 2009). Over the same period, the upper house of the parliament led a two-year investigation to determine important guidelines for local governments and their use of derivatives in the future (Italian Parliament, 2010a).

Eventually, the short-lived government led by Enrico Letta made a complete volte-face in December 2013 and opted to transform the moratorium into a long-term solution. Thus, Italian local governments are now permanently prohibited from using derivatives, except in instances in which they intend to purchase interest rate caps on their actual loans (Cherubini, 2013; Italian Parliament, 2013). Municipalities now face the choice of either closing out their existing positions - most likely at a loss - or renegotiating them (Reuters, 2013). Alternatively, they can file lawsuits against financial intermediaries to attempt to invalidate their contracts. In this regard, media attention has focused on several trials such as the well-known case concerning the City of Milan against Deutsche Bank, JPMorgan, UBS and DePfa Bank (Martinuzzi, 2013; Sirletti \& Martinuzzi, 2014).

It is worth noting similar experiences in other countries as Italian 
municipalities were not the only parties that entered OTC derivatives markets. Certainly, they were notable for the extensive way in which derivatives were employed in public finance (Sanderson, et al., 2010) - a characterization that also applied to the central government and its adoption of derivatives-based techniques in the run-up to EMU entry during the 1990s (Dinmore, 2013a; 2013b; FT, 2013; Gabanelli, 2014; Penati, 2012; Piga, 2001; Steil, 2002). Yet, ever since swaps emerged in the United States during the early 1980s, episodes of derivatives debacles involving local authorities have been a recurrent phenomenon (Geisst, 2002; Markham, 2002; Swan, 1999). More important, most cases show that these practices vary on the basis of context-specific political struggles that unfold at different geographical scales.

For instance, the infamous case of Orange County - which filed for bankruptcy protection in 1994 after losing approximately \$1.7 billion in derivatives transactions - occurred in a context in which "politics in California had created a situation that made extraordinary returns for municipalities a godsend” (Geisst, 2002: 320). This situation arose because - in a widespread popular spurning of high taxation (especially on property) - the state passed Proposition 13, which limited local authorities’ ability to raise taxes. Such limitations led to a shortfall in municipal revenues that needed to be compensated by some other means. In this context, the strategies developed by the Orange County Investment Pool and its treasurer Bob Citron were effective for a long period (Baldassare, 1998).

More recently, French and German municipalities also engaged in complex derivatives transactions during the same years in which their Italian peers were enticed into financial innovation (Dodd, 2010). For example, the city of Saint Etienne in France was exposed to a negative market value on its derivatives position of 
approximately $€ 100$ million in 2010 (Katz, 2010). In Germany, the city of Pforzheim incurred losses on its derivatives transactions of approximately $€ 57$ million (Hendrikse \& Sidaway, 2013). These instances of financial excess in present-day Europe highlight three aspects that - similar to the Italian case - played a central role in encouraging local governments to embrace derivatives. First, municipalities strove for revenues while facing unsustainable pressures stemming from a regime of fiscal consolidation. Second, the devolution of fiscal and administrative management to the sub-national level led to a lack of effective supervision over myriad fragmented local interests and their access to complex - often completely unknown - financial practices. Third, austerity and devolution encouraged municipalities to embrace market-based financing as a tactical response to the reduction in public expenditure. Although municipalities underestimated the risks of being exposed to financial volatility, these strategies represented a powerful political message in opposition to European-wide austerity programmes.

\section{Conclusions}

In one of his most famous and insightful passages, Foucault (1977: 176-7) described disciplinary power as follows:

[It is] organized as a multiple, automatic and anonymous power; for although surveillance rests on individuals, its functioning is that of a network of relations from top to bottom, but also to a certain extent from bottom to top and laterally; this network 'holds' the whole together and traverses it in its entirety with effects of power that derive from one another: supervisors, perpetually supervised. The power in 
the hierarchized surveillance of the disciplines is not possessed as a thing, or transferred as a property; it functions like a piece of machinery. And, although it is true that its pyramidal organization gives it a 'head', it is the apparatus as a whole that produces 'power' and distributes individuals in this permanent and continuous field.

Foucauldian political economists adopt this definition of disciplinary power to explain how individuals perform financial affairs as a widespread and depoliticized apparatus of human discipline (Aitken, 2007; De Goede, 2005; Langley, 2009). Foucauldians emphasize the diffuse and performative character of financialized power rather than its 'pyramidal organization' - that is, the asymmetrical relations amongst the actors constituting it. However, this perspective fails to provide the appropriate analytical tools to capture the agency and political conflicts shaping financialized processes in their context-specific features. For this reason, Foucauldians cannot easily account for the varieties of financialization and the politics underlying such diversity (Engelen, et al., 2010; Engelen \& Konings, 2010: 608-9; Montgomerie, 2008: 241; Nölke, et al., 2013).

This article has constructively engaged with Foucauldian studies on presentday financial expansion. It has advanced the contention that the dimension of power should be operationalized at the level of historical agents and the institutions mediating agential relations. In this context, actors should be understood not as passive performers of financialization and its depoliticized market-based practices but as agents interacting with one another through the mediation of constantly renegotiated financialized institutions. In so doing, power becomes the agential ability to shape these mediating structures and leverage one's own position vis-à-vis others (Knafo, 2010; Konings, 2010). This conceptual framework avoids the risk of reifying 
power by being sensitive to the concrete politics producing financialization in distinct institutional contexts.

Drawing on this agency-centred approach, the article has examined the case of Italian municipalities and their use of interest rate swaps during the 2000-2014 period. It has proceeded in three steps.

First, the study has explored the agents, power struggles and processes of institutional construction that led to the introduction of financial derivatives in Italian local finance. It has shown that neoliberal reformists came to power in Italy during the 1990s and challenged the traditional political-cum-business establishment by implementing fiscal austerity and liberalization measures under the auspices of the EMU and the Stability and Growth Pact. In addition to this, neoliberal reformists pushed for the devolution of fiscal and administrative authority. On the one hand, Italy's adherence to the Stability and Growth Pact resulted in a reduction of fund transfers from the central state to the sub-sovereign level. On the other hand, devolution gave local authorities greater autonomy in the management of their finances and the possibility to use bonds and derivatives. These two trends created an institutional context in which local governments familiarized themselves with the methods and instruments of market-based finance. From 2001 onwards, the Berlusconi government enacted a regulatory framework to oversee the use of derivatives in local finance. This regulation contained loopholes that many local authorities exploited in unconventional ways.

Second, the work has investigated the specific derivatives techniques that Italian municipalities employed. At first glance, the municipal adoption of interest rate swaps appears as a form of depoliticized performativity in which local administrators embraced the financialized discourse of derivatives-based risk 
management. However, in contrast to such perspective, this article has argued that Italian municipalities used swaps as accounting artifices to circumvent the budget limits imposed by the Stability and Growth Pact. Far from performing and depoliticizing the use of swaps - as Foucauldian scholars would conclude - Italian local authorities wielded these instruments as part of a highly politicized strategy, the objective of which was to confront an unsustainable regime of fiscal austerity. While doing so, local governments enabled financial innovation to spread as a variegated and politically shaped phenomenon.

Finally, the study has concluded with a review of the current developments in Italian local finance, particularly concerning the permanent ban on the use of derivatives by local authorities. The section has also referred to the derivatives excesses of other countries and how these were the result of context-specific political struggles against austerity programmes.

\section{Acknowledgements}

COST Action IS0902 provided financial support to this research (ECOSTSTSM-IS0902-060812-019528). I wish to thank Mirjam Büdenbender, Duncan Wigan, Earl Gammon, Oliver Kessler, Bob Jessop, Benjamin Wilhelm and the two anonymous reviewers for their helpful comments. The usual disclaimers apply.

\footnotetext{
${ }^{1}$ The financialization debate emerged more than a decade ago, providing an important intellectual terrain for critical scholars of diverse theoretical and disciplinary backgrounds. For a recent review, see Van der Zwan (2014). Financialization is commonly defined as "the increasing role of financial motives, financial markets, financial actors and financial institutions in the operation of the domestic
} 
and international economies” (Epstein, 2005: 3).

${ }^{2}$ Derivatives are highly speculative contracts, the value of which derives from the price movements of other assets and variables. See Hull (2009: 1-16) for a brief introduction on derivatives markets, instruments and actors. Derivatives provide a fundamental function of risk management in the economy, and this innovative role stems from their ability to produce - at least theoretically - a complete market in the sense given by Arrow \& Debreu (1954). According to this perspective, myriad derivatives would allow one to hedge the risks stemming from all future states of the world - for a critical examination of this thesis, see Wigan (2009) and Bryan \& Rafferty (2006, 2011). However, as the 2007-2008 financial meltdown clearly demonstrated, the speculative nature of these instruments often overcomes their risk-management function, potentially leading to full-blown crises (Greenberger, 2010). Derivatives most emblematically reflect the rise of finance (or financialization) in present-day capitalism. The global notional value of OTC derivatives markets was $\$ 691$ trillion at the end of June 2014 (BIS, 2014) - approximately ten times the gross world product (IMF, 2014: 184).

${ }^{3}$ OTC derivatives markets are vast and decentralized networks in which financial actors trade nonstandardized instruments without central counterparties intermediating between buyers and sellers. Compared with organized exchanges, trading on OTC markets implies a considerably higher exposure to risk (Hull, 2009: 1-3).

${ }^{4}$ Paulson was the United States Secretary of the Treasury and also a former chief executive officer of Goldman Sachs. Fuld was chief executive officer of Lehman Brothers. See Sorkin (2009).

${ }^{5}$ In Italy, local authorities refer to municipalities, provinces, metropolitan cities and regions (Italian Constitution, 1947). This study particularly focuses on municipalities.

${ }^{6}$ Neoliberalism denotes the ideology according to which "human well-being can best be advanced by liberating individual entrepreneurial freedoms and skills within an institutional framework characterized by strong private property rights, free markets, and free trade” (Harvey, 2005: 2). The emphasis on the free market and the retreat of the state is a rhetorical matter. In reality, neoliberal forces capture state institutions and exploit them to secure their disciplinary role over society (Konings, 2009a).

${ }^{7}$ Ironically, the very same Italian expression now refers to financial derivatives in their general features and use. 
${ }^{8}$ This regulatory framework can be summarized in the following six points: 1) Municipalities were allowed to use derivatives only for hedging purposes and on the basis of existing liabilities. 2) They were obliged to use currency swaps when issuing bonds in foreign currencies, as well as amortizing swaps when issuing bonds (or taking out loans) with single repayments at maturity. 3) Municipalities were allowed to use currency swaps, interest rate swaps, forward rate agreements, amortizing swaps and interest rate options (caps, collars). 4) They could have restructured their debt positions but could not have done so with the objective of postponing the maturity of the initial debt. Moreover, these operations could not have included an upfront sum above 1 per cent of the notional amount or an increasing flow of payments by the local authority to the counterparty over the duration of the contract. 5) Local governments were obliged to enter into contracts with highly creditworthy dealers only and by using G7-area monetary parameters. Moreover, for contracts of approximately $€ 100$ million (notional value), they should have limited exposure to a single intermediary at 25 per cent of the total notional amount. 6) The Ministry of Economy and Finance (MEF) was responsible for monitoring derivatives activities every three months (Franco, 2009: 18-22, table 4). The Bank of Italy and the Italian securities market authority (CONSOB) were both responsible for controlling financial intermediaries and their derivatives operations with local authorities (Rosati, 2009: 9-11, 15-8).

${ }^{9}$ In the same period, the Berlusconi government launched the largest disinvestment of state-owned real estate in Europe through securitization. This opaque operation avoided the need to raise taxes or cut expenditures without breaching the deficit ceiling of 3 per cent (Corte dei Conti, 2006: 34; Munter, 2004). Furthermore, the government implemented tax amnesties on repatriated offshore accounts and decriminalized corporate accounting fraud (Flores D’Arcais, 2011: 133; Ginsborg, 2003: 48).

${ }^{10}$ The following case is based on two interviews (September 04-05, 2012) with the head of financial services of the municipality in question. The interviewee kindly provided official documents after request to the mayor.

${ }^{11}$ Before the enactment of the European Market in Financial Instruments Directive (MiFID) in 2007, Italian local authorities had signed a controversial declaration in which they simply agreed to be considered operatori qualificati. See CONSOB (1998). 


\section{References}

Aitken, R. 2007. Performing Capital: Toward a Cultural Economy of Popular and Global Finance. New York: Palgrave Macmillan.

Alonso, S. 2012. Challenging the State: Devolution and the Battle for Partisan Credibility: A Comparison of Belgium, Italy, Spain, and the United Kingdom. Oxford: Oxford University Press.

Arrow, K. \& Debreu, G. 1954. Existence of an Equilibrium for a Competitive Economy.” Econometrica, 22(3): 265-90.

Baldassare, M. 1998. When Government Fails. Berkeley: University of California Press.

Bankitalia. 2009. Debito delle Amministrazioni Locali. Bank of Italy [online]. Accessed on 30 December 2014. Available at: $<$ https://www.bancaditalia.it/pubblicazioni/debito-amministrazioni/>

Bankitalia. 2014. Debito delle Amministrazioni Locali. Bank of Italy [online], 31 October. Accessed on 30 December 2014. Available at: $<$ https://www.bancaditalia.it/pubblicazioni/debito-amministrazioni/>

Berger, P.L. \& Luckmann, T. 1966. The Social Construction of Reality: A Treatise in the Sociology of Knowledge. Garden City, NY: Anchor Books.

Bianchi, P. 1987. The IRI in Italy: Strategic Role and Political Constraints. West European Politics, 10(2): 269-90.

BIS. 2014. Derivatives Statistics. Bank for International Settlements [online], 6 November. Accessed on 9 November 2014. Available at: $<$ http://www.bis.org/publ/otc_hy1411.htm>.

Bryan, D. \& Rafferty, M. 2006. Capitalism with Derivatives. A Political Economy of Financial Derivatives, Capital and Class. Basingstoke: Palgrave Macmillan.

Bryan, D. \& Rafferty, M. 2011. Deriving Capital's (and Labour's) Future. Socialist Register, 47: 196-223.

Carlini, V. 2010. Ecco come la Finanza Creativa Ha Danneggiato gli Enti Pubblici. Il Sole 24 Ore [online], 22 March. Accessed on 20 December 2014. Available at: $<$ http://www.ilsole24ore.com/art/SoleOnLine4/Finanza\%20e\%20Mercati/201 0/03/derivati-comuni-truffa-raggiro-ente-pubblico-P_A.shtml>.

Cassard, M. \& Folkerts-Landau, D. 1997. Risk Management of Sovereign Assets and Liabilities. International Monetary Fund, Working Paper 97/166.

Cherubini, U. 2013. Derivati, Letta Concede alle Banche di Gabbare i Comuni. Linkiesta.it [online], 25 November. Accessed on 20 December 2014. Available at: <http://www.linkiesta.it/derivati-enti-locali-legge-stabilita>. 
CONSOB. 1998. Regolamento n. 11522 (Intermediari). Commissione Nazionale per le Società e la Borsa [online], 1 July. Accessed on 1 November 2014.

Available at:

$<$ http://www.consob.it/main/regolamentazione/tuf/storico_intermediari_11522 .html>.

Corte dei Conti. 2006. Analisi dei Risultati delle Cartolarizzazioni. Corte dei Conti Sezione centrale di controllo sulla gestione delle Amministrazioni dello Stato [online], 21 March. Accessed on 30 November 2014. Available at:

$<$ http://www.camera.it/cartellecomuni/leg14/RapportoAttivitaCommissioni/co mmissioni/allegati/05/05_all_corteconti.pdf $>$.

Deeg, R. 2005. Remaking Italian Capitalism? The Politics of Corporate Governance Reform. West European Politics, 28(3): 521-48.

De Goede, M. 2005. Virtue, Fortune, and Faith. A Genealogy of Finance. Minneapolis: University of Minnesota Press.

De Goede, M. 2006. Introduction: International Political Economy and the Promises of Poststructuralism. In: M. De Goede, eds. International Political Economy and Poststructural Politics. Basingstoke: Palgrave, pp. 1-20.

Dinmore, G. 2013a. Italy Faces Restructured Derivatives Hit. Financial Times [online], 26 June. Accessed on 30 December, 2014. Available at: $<$ http://www.ft.com/intl/cms/s/0/440007a8-dd9a-11e2-a75600144feab7de.html>.

Dinmore, G. 2013b. Italy Probes Use of Derivatives to Hedge Public Debt.” Financial Times [online], 26 June. Accessed on 30 December 2014. Available at: $<$ http://www.ft.com/intl/cms/s/0/3a9a78f4-de69-11e2-b99000144feab7de.html>.

Dodd, R. 2010. Municipal Bombs. Finance \& Development, 47(2): 33-35.

Dyson, K. \& Featherstone, K. 1996. Italy and EMU as a 'Vincolo Esterno': Empowering the Technocrats, Transforming the State. South European Society and Politics, 1(2): 272-99.

Emirbayer, M. \& Mische, A. 1998. What Is Agency? American Journal of Sociology, 103(4): 962-1023.

Engelen, E. \& Konings, M. 2010. Financial Capitalism Resurgent. Comparative Institutionalism and the Challenges of Financialization. In: G. Morgan, J. Campbell, C. Crouch, O.K. Pedersen and R. Whitley, eds. Oxford Handbook of Comparative Institutionalism. Oxford: Oxford University Press, pp. 60124.

Engelen, E., Konings, M. \& Fernandez, R. 2010. Geographies of Financialization in Disarray: The Dutch Case in Comparative Perspective. Economic Geography, 86(1): 53-73.

Epstein, G.A. 2005. Introduction: Financialization and the World Economy. In: G.A. 
Epstein, eds. Financialization and the World Economy. Northampton, MA: Edward Elgar, pp. 3-16.

Flores D’Arcais, P. 2011. Anatomy of Berlusconismo. New Left Review, 68: 121-40.

Foucault, M. 1977. Discipline and Punish. The Birth of the Prison. New York: Vintage Books.

Franco, D. 2009. Indagine Conoscitiva sull’Utilizzo e la Diffusione degli Strumenti di Finanza Derivata e delle Cartolarizzazioni nelle Pubbliche Amministrazioni. Audizione del Capo del Servizio Studi di Struttura Economica e Finanziaria della Banca d’Italia. Senato della Repubblica, Commissione 6a [online], 8 July. Accessed on 30 November 2014. Available at:

$<$ http://www.bancaditalia.it/pubblicazioni/interventi-vari/int-var2009/Audizione_Senato_080709.pdf>.

FSB. 2010. Implementing OTC Derivatives Market Reforms. Financial Stability Board [online], 25 October. Accessed on 30 December 2014. Available at: $<$ http://www.financialstabilityboard.org/2010/10/fsb-report-on-implementingotc-derivatives-market-reforms/>.

FT. 2013. Embellished Figures. Financial Times [online], 26 June. Accessed on 30 December 2014. Available at: <http://www.ft.com/intl/cms/s/0/a61565f2de56-11e2-b990-00144feab7de.html>.

Gabanelli, M. 2014. Il Tesoro Tira Dritto sui Derivati dello Stato: 8 Miliardi in Garanzia alle Banche d’Affari Estere. Corriere della Sera [online], 23 December. Accessed on 30 December 2014. Available at: $<$ http://www.corriere.it/inchieste/reportime/economia/tesoro-tira-drittoderivati-stato-8-miliardi-garanzia-banche-d-affari-estere/8f88d6e6-8a19-11e4a99b-e824d44ec40b.shtml>.

Galli Della Loggia, E. 2013. Élite Locali e Clientelismo Selvaggio. Il (Brutto) Volto del Federalismo. Corriere Della Sera [online], 1 October. Accessed on 20 December 2014. Available at: <http://www.corriere.it/cronache/13_ottobre_01/caso-umbria-clientelismoselvaggio_4d64d328-2a61-11e3-b898-f13adc0c04f6.shtml>.

Geisst, C.R. 2002. Wheels of Fortune. The History of Speculation from Scandal to Respectability. Hoboken: Wiley.

Ginsborg, P. 2001. Italy and Its Discontents, 1980-2001. London: Penguin Books.

Ginsborg, P. 2003. The Patrimonial Ambitions of Silvio B. New Left Review, 21: 2164.

Greenberger, M. 2010. "The Role of Derivatives in the Financial Crisis - Testimony before the Financial Crisis Inquiry Commission, June 30, 2010.” Retrieved November 9, 2014 (http://works.bepress.com/michael_greenberger/33).

Harvey, D. 2005. A Brief History of Neoliberalism. Oxford: Oxford University Press. 
Heipertz, M. \& Verdun, A. 2004. The Dog that Would never Bite? What We Can Learn from the Origins of the Stability and Growth Pact. Journal of European Public Policy, 11(5): 765-80.

Heipertz, M. \& Verdun, A. 2005. The Stability and Growth Pact - Theorizing a Case in European Integration. Journal of Common Market Studies, 43(5): 9851008.

Hendrikse, R.P. \& Sidaway, J.D. 2013. Financial Wizardry and the Golden City: Tracking the Financial Crisis through Pforzheim, Germany. Transactions of the Institute of British Geographers, 39(2): 195-208.

Hopkin, J. 2008. Decentralisation and Party Organisational Change: The Case of Italy. In: W. Swenden and B. Maddens, eds. Territorial Party Politics in Western Europe. Basingstoke: Palgrave Macmillan, pp. 86-101.

Hull, J.C. 2009. Options, Futures, and Other Derivatives. Upper Saddle River: Pearson Education.

IMF. 2014. World Economic Outlook October. Legacies, Clouds, Uncertainties. Washington, DC: International Monetary Fund.

Italian Constitution. 1947. Constitution of the Italian Republic. Presidenza della Repubblica Italiana [online], 27 December. Accessed on 30 November 2014. Available at: $<$ http://www.senato.it/documenti/repository/istituzione/costituzione_inglese.p $\mathrm{df}>$.

Italian Government. 2000. Decreto Legge n. 267. Governo della Repubblica Italiana [online], 18 August. Accessed on 30 November 2014. Available at: $<$ http://www.normattiva.it $>$.

Italian Government. 2008. Decreto Legge n. 112 (Articolo 62). Governo della Repubblica Italiana [online], 25 June. Accessed on 30 November 2014. Available at: <http://www.normattiva.it>.

Italian Parliament. 1994. Legge n. 724 (Articolo 35). Parlamento della Repubblica Italiana [online], 23 December. Accessed on 30 November 2014. Available at: $<$ http://www.normattiva.it>.

Italian Parliament. 1997a. Legge n. 127. Parlamento della Repubblica Italiana [online], 15 May. Accessed on 30 November 2014. Available at: $<$ http://www.normattiva.it $>$.

Italian Parliament. 1997b. Legge n. 59. Parlamento della Repubblica Italiana [online], 15 March. Accessed on 30 November 2014. Available at: $<$ http://www.normattiva.it $>$.

Italian Parliament. 1998. Legge n. 191. Parlamento della Repubblica Italiana [online], 16 June. Accessed on 30 November 2014. Available at: $<$ http://www.normattiva.it>. 
Italian Parliament. 1999a. Legge n. 488. Parlamento della Repubblica Italiana [online], 23 December. Accessed on 30 November 2014. Available at: $<$ http://www.normattiva.it>.

Italian Parliament. 1999b. Legge n. 50. Parlamento della Repubblica Italiana [online], 8 March. Accessed on 30 November 2014. Available at: $<$ http://www.normattiva.it>.

Italian Parliament. 2001a. Legge Costituzionale n. 3. Parlamento della Repubblica Italiana [online], 18 October. Accessed on 30 November 2014. Available at: $<$ http://www.normattiva.it $>$.

Italian Parliament. 2001b. Legge n. 448 (Articolo 41, Paragrafo 2). Parlamento della Repubblica Italiana [online], 28 December. Accessed on 30 November 2014. Available at: <http://www.normattiva.it>.

Italian Parliament. 2003. Legge n. 350 (Articolo 3, 16-21ter). Parlamento della Repubblica Italiana [online], 24 December. Accessed on 30 November 2014. Available at: <http://www.normattiva.it>.

Italian Parliament. 2006. Legge n. 296 (Articolo 1, 736-739). Parlamento della Repubblica Italiana [online], 27 December. Accessed on 30 November 2014. Available at: <http://www.normattiva.it>.

Italian Parliament. 2008a. Legge n. 133 (Articolo 62). Parlamento della Repubblica Italiana [online], 6 August. Accessed on 30 November 2014. Available at: $<$ http://www.normattiva.it>.

Italian Parliament. 2008b. Legge n. 203 (Articolo 3). Parlamento della Repubblica Italiana [online], 22 December. Accessed on 30 November 2014. Available at: $<$ http://www.normattiva.it $>$.

Italian Parliament. 2010a. Indagine Conoscitiva sull'Utilizzo e la Diffusione degli Strumenti di Finanza Derivata e delle Cartolarizzazioni nelle Pubbliche Amministrazioni (Documento Conclusivo). Parlamento della Repubblica Italiana, Senato della Repubblica, Commissione 6a [online], 11 March. Accessed on 1 November 2014. Availabe at: <http://www.parlamento.it/service/PDF/PDFServer/BGT/470072.pdf>.

Italian Parliament. 2010b. Indagine Conoscitiva sulla Finanza Locale. Parlamento della Repubblica Italiana, Camera dei Deputati, 5 a Commissione Permanente [online], 28 September. Accessed on 30 November 2014. Available at: $<$ http://documenti.camera.it/_dati/leg16/lavori/documentiparlamentari/indiceet esti/017/009/intero.pdf>.

Italian Parliament. 2013. Legge n. 147 (Articolo 1, Paragrafo 572). Parlamento della Repubblica Italiana [online], 27 December. Accessed on 1 November 2014. Available at: <http//:www.normattiva.it>.

Katz, A. 2010. The City that Got Swapped. BusinessWeek: Magazine [online], 22 April. Accessed on 6 November 2014. Available at: <http://www.businessweek.com/magazine/content/10_18/b4176100989666.ht 
$\mathrm{m}>$.

Knafo, S. 2010. Critical Approaches and the Legacy of the Agent/Structure Debate in International Relations. Cambridge Review of International Affairs, 23(3): 493-516.

Konings, M. 2009a. Rethinking Neoliberalism and the Subprime Crisis: Beyond the Re-Regulation Agenda. Competition \& Change, 13(2): 108-27.

Konings, M. 2009b. The Construction of US Financial Power. Review of International Studies, 35(1): 69-94.

Konings, M. 2010. The Pragmatic Sources of Modern Power. European Journal of Sociology, 51(1): 55-91.

Lagna, A. 2015. Derivatives as Weapons of Mass Deception and Elite Contestation: The Case of FIAT. In: B. Jessop, B. Young and C. Scherrer, eds. Financial Cultures and Crisis Dynamics. Abingdon: Routledge, pp. 208-28.

Langley, P. 2009. The Everyday Life of Global Finance: Saving and Borrowing in Anglo-America. Oxford: Oxford University Press.

Markham, J.W. 2002. A Financial History of the United States. From the Age of Derivatives into the New Millennium (1970-2001). Armonk: M. E. Sharpe.

Martinuzzi, E. 2013. JPMorgan, UBS Tricked Milan in Swaps Case, Judge Says. Bloomberg [online], 4 February. Accessed on 30 November 2014. Available at: $<$ http://www.bloomberg.com/news/2013-02-04/jpmorgan-deutsche-banktricked-milan-in-swaps-case-judge-says.html>.

MEF. 1996. Decreto Ministeriale n. 420. Ministero dell'Economia e Finanze [online], 5 July. Accessed on 30 November 2014. Available at:

$<$ http://www.dt.tesoro.it/it/debito_pubblico/enti_locali/nota_espl_normativa_e nti_territoriali.html>.

MEF. 2003. Decreto Ministeriale n. 389. Ministero dell'Economia e Finanze [online], 1 December. Accessed on 1 November 2014. Available on:

$<$ http://www.dt.tesoro.it/it/debito_pubblico/enti_locali/nota_espl_normativa_e nti_territoriali.html $>$.

MEF. 2004. Circolare (27 Maggio 2004). Ministero dell'Economia e Finanze [online], 27 May. Accessed on 1 November 2014. Available at:

$<$ http://www.dt.tesoro.it/it/debito_pubblico/enti_locali/nota_espl_normativa_e nti_territoriali.html>.

MEF. 2007a. Circolare (22 Giugno 2007). Ministero dell'Economia e Finanze [online], 22 June. Accessed on 1 November 2014. Available at:

$<$ http://www.dt.tesoro.it/it/debito_pubblico/enti_locali/nota_espl_normativa_e nti_territoriali.html>.

MEF. 2007b. Circolare (31 Gennaio 2007). Ministero dell'Economia e Finanze [online], 31 January. Accessed on 1 November 2014. Available at: 
<http://www.dt.tesoro.it/it/debito_pubblico/enti_locali/nota_espl_normativa_e nti_territoriali.html>.

MEF. 2009. Schema di Regolamento Ministeriale di Attuazione dell'Articolo 62 del Decreto Legge 25 Giugno 2008, N. 112, Convertito con Modificazioni dalla Legge 6 Agosto 2008, N. 133, come Sostituito dall'Articolo 3 della Legge 22 Dicembre 2008, N. 203 (Documento di Consultazione). Ministero dell'Economia e Finanze [online], 22 September. Accessed on 1 November 2014. Available at:

$<$ http://www.dt.tesoro.it/export/sites/sitodt/modules/documenti_it/regolamenta zione_bancaria_finanziaria/consultazioni_pubbliche/Derivati_enti_locali__regolamento_ex_articolo_62_d.l.pdf>.

Montgomerie, J. 2008. Bridging the Critical Divide: Global Finance, Financialisation and Contemporary Capitalism. Contemporary Politics, 14(3): 233-52.

Munter, P. 2004. The Italian Experience: Flair Keeps Deficit in Check. Financial Times, 29 November, p. 3.

Nölke, A., Heires, M. \& Bieling, H.J. 2013. Editorial: The Politics of Financialization. Competition \& Change, 17(3): 209-18.

Pasquino, G. 2000. Political Development. In: P. McCarthy, eds. Italy since 1945. Oxford: Oxford University Press, pp. 69-94.

Penati, A. 2012. Troppi Rischi e Scarsa Trasparenza. È Ora di Dire Basta ai Derivati di Stato. La Repubblica [online], 18 March. Accessed on 30 November 2014. Available at:

<http://www.repubblica.it/economia/2012/03/18/news/troppi_rischi_e_scarsa_ trasparenza_ora_di_dire_basta_ai_derivati_di_stato-31765159/>.

Piga, G. 2001. Derivatives and Public Debt Management. Zurich, New York: International Securities Market Association - Council for Foreign Relations.

Quaglia, L. 2004. Italy’s Policy towards European Monetary Integration: Bringing Ideas Back In? Journal of European Public Policy, 11(6): 1096-1111.

Reuters. 2013. Derivati, Cala Esposizione Enti Territoriali, soprattutto Comuni. Reuters Italia [online], 18 October. Accessed on 1 November 2014. Available at: <http://it.reuters.com/article/itEuroRpt/idITL6N0I82FX20131018>.

Rosati, A. 2009. Indagine Conoscitiva sulla Diffusione degli Strumenti di Finanza Derivata e delle Cartolarizzazioni nelle Pubbliche Amministrazioni. Audizione del Direttore Generale della Consob. Senato della Repubblica, Commissione $6 a$ [online], 18 March. Accessed on 30 November 2014. Available at: $<$ www.consob.it/documenti/Pubblicazioni/Audizioni/audizione_rosati_200903 18.pdf $>$.

Saccomanni, F. 2007. Le Problematiche Relative agli Strumenti Finanziari Derivati. Audizione informale del Direttore Generale della Banca d'Italia, Parlamento della Repubblica Italiana, Camera dei Deputati, 6a Commissione Permanente [online], 6 November. Accessed on 30 November 2014. Available at: 
$<$ http://www.bancaditalia.it/pubblicazioni/interventi-direttorio/int-dir2007/saccomanni_061107.pdf>.

Sanderson, R., Dinmore, G. \& Tett, G. 2010. Finance: An Exposed Position.

Financial Times [online], 8 March. Accessed on 30 November 2014. Available at: <http://www.ft.com/cms/s/0/0d29fbdc-2aef-11df-886b00144feabdc0.html $>$.

Sbragia, A. 2001. Italy Pays for Europe: Political Leadership, Political Choice, and Institutional Adaptation. In: M. Green Cowles, J. Caporaso, and T. Risse, eds. Transforming Europe. Europeanization and Domestic Change. Ithaca: Cornell University Press, pp. 79-96.

Sirletti, S. \& Martinuzzi, E. 2014. JPMorgan, UBS Convictions Overturned in Milan Swaps Case. Bloomberg [online], 7 March. Accessed on 6 November 2014. Available at: <http://www.bloomberg.com/news/2014-03-07/jpmorgan-ubsconvictions-overturned-in-milan-swaps-case.html>.

Sorkin, A.R. 2009. Too Big to Fail. The Inside Story of How Wall Street and Washington Fought to Save the Financial System - and Themselves. New York: Penguin Books.

Steil, B. 2002. Enron and Italy. Financial Times, 21 February, pp. n/a.

Swan, E.J. 1999. Building the Global Market, a 4000 Year History of Derivatives. London: Kluwer Law International.

Van der Zwan, N. 2014. Making Sense of Financialization. Socio-Economic Review, 12(1): 99-129.

Wigan, D. 2009. Financialisation and Derivatives: Constructing an Artifice of Indifference. Competition \& Change, 13(2): 157-72. 